\title{
Simple and Direct Characterization of Leishmania donovani Isolates Based on Cytochrome Oxidase II Gene Sequences
}

\author{
Abdalla Hassan Sharief*, ${ }^{*}$, El-Tahir Awad Gasim Khali1², Douglas Cameron Barker ${ }^{3}$, \\ Samia Ali Omer ${ }^{1}$, Hamid Suliman Abdalla ${ }^{4}$ and Muntasir Eltayeb Ibrahim ${ }^{2}$ \\ ${ }^{I}$ Department of Immunology, Tropical Medicine Research Institute, National Center for Research, Khartoum, Sudan \\ ${ }^{2}$ Department of Molecular Biology, Institute of Endemic diseases, University of Khartoum, Khartoum, Sudan \\ ${ }^{3}$ School of Biological Sciences, Department of Pathology, University of Cambridge, UK \\ ${ }^{4}$ Department of Parasitology, Faculty of Veterinary Medicine, University of Khartoum, Khartoum, Sudan
}

\begin{abstract}
We primarily identified Leishmania donovani parasites from eastern Sudan using species-specific primers that amplify a whole length minicircle. Based on the amplification of a cytochrome oxidase II fragment (COII), heteroduplex analysis (HDA) was performed. In HDA, the appearance of the extra bands with molecular weights higher than 540 bp indicates the presence of mismatched bases in the selected samples. Such bands were detected when hybridization was between reference strains and clinical isolates, as well as between the reference strains themselves, while no heteroduplexes were detected between the clinical isolates. Moreover, an RFLP assay using the restriction enzyme $S s p 1$ was performed on the original $540 \mathrm{bp}$ products to discern an A-G transition, which differentiates between members of the Leishmania $(L)$ infantum and those of Leishmania $(L)$ donovani subspecies. The proposed minicircle genes-based analysis was rapid and easy to perform method for the characterization of Leishmania donovani complex isolates and with a potential to be extended to characterization of other species of Leishmania.
\end{abstract}

Keywords: Leishmania donovani, heteroduplex analysis, COII gene, characterization, Sudan.

\section{INTRODUCTION}

Differences in clinical presentations and severity of the leishmaniases are explained by interactions between particular molecular and biologic characteristics of different Leishmania species, host genetics and immunity and, environmental factors $[1,2]$. Although it is generally accepted that major clinical forms of leishmaniasis may be caused by specific Leishmania species, the relationship between Leishmania zymodemes and clinical presentation remains unclear [3]. To date, most studies investigating the relationship between polymorphisms and clinical disease have provided little evidence for strong associations $[4,5]$. The method of choice for characterization of Leishmania is isoenzyme analysis [6] which has the disadvantages of being tedious, time consuming and requires the use of toxic substances. Other techniques for characterizing Leishmania species that have been developed include biochemical and molecular characterization, isoenzyme characterization, genetic typing. [7,8]. Recently PCR-based techniques have introduced and proved capability of identifying Leishmania species. The advantage of PCR-based characterization is sufficient to distinguish almost all medically relevant Leishmania species including L. major, L. tropica and $L$. infantum [9-14]. Discrimination between L.donovani and L.infantum is very much needed to type Leishmania isolates

*Address correspondence to this author at the Tropical Medicine Research Institute, National Centre for Research, Khartoum, P.O. Box 1304, Sudan; Tel: + $249183777501 ;$ Fax: + 249183781845 ;

E-mail: abdullasharief@postmaster.co.uk using a PCR-based technique that introduced for the first time. Leishmania donovani and Leishmania infantum both pertain to the $L$. (L.) donovani complex. The status of certain strains is questioned in the literature and there are no reliable discriminative markers to identify them. Molecular tools are much needed to identify diagnostic markers and to allow a better understanding of phylogenetic relationships. In this study we have developed simple and direct method of Leishmania characterization based on cytochrome oxidase gene sequences. This PCR discriminates between members of the Leishmania donovani complex with a future potential to be applied for characterizing L.major and L.tropica complexes.

\section{MATERIALS AND METHODS}

\section{Parasites}

Leishmania parasite strains were isolated from visceral leishmaniasis (VL) patients living in a cluster of villages, within VL endemic area, in eastern Sudan. Bone marrow and/or lymph node aspirates were taken and inoculated into bottles containing culture media. L.donovani and L.infantum reference strains were obtained from the Cryobank of the NIMR Outstation, Molteno Laboratory, Department of Pathology, University of Cambridge.

\section{Genomic DNA Extraction}

Promastigotes (clinical isolates) were cultured at $24^{\circ} \mathrm{C}$ in RPMI-1640 medium containing $15 \%$ fetal calf serum. 
Parasites were harvested at a density of $2 \times 10^{7}$ parasites $/ \mathrm{ml}$, pelleted at $2,000 \mathrm{~g}$ for $8 \mathrm{~min}$ at $4^{\circ} \mathrm{C}$, washed 3 times in phosphate-buffered balanced salt solution (PBSS) $\mathrm{pH} 7.4$, and then re-suspended in $500 \mathrm{ml}$ PBSS. The DNA was extracted using salt extraction method according to Miller [15]. Briefly, parasite pellet was digested with $20 \mathrm{mg} / \mathrm{ml}$ proteinase $\mathrm{K}(400 \mu \mathrm{g} / \mathrm{ml}$ final concentration) was added and mixed well. The suspension was incubated at $55-65^{\circ} \mathrm{C}$ overnight, after which $300 \mu \mathrm{l}$ of $6 \mathrm{M} \mathrm{NaCl}(\mathrm{NaCl}$ saturated $\mathrm{H}_{2} \mathrm{O}$ ) was added. Samples were vortexed for 30 seconds at maximum speed, and tubes spun down for 30 minutes at $10,000 \mathrm{~g}$. The supernatant was transferred to fresh tubes. An equal volume of isopropanol was added to each sample, mixed well, and samples were stored at $-20^{\circ} \mathrm{C}$ for $1 \mathrm{~h}$. Samples were then centrifuged for $20 \mathrm{~min}, 4^{\circ} \mathrm{C}$, at $10000 \mathrm{~g}$. The pellet was washed with $70 \%$ ethanol, dried and finally re-suspended in 300-500 $\mu \mathrm{l}$ sterile $\mathrm{dH}_{2} \mathrm{O}$. Genomic DNA (5$15 \mathrm{ng}$ ) in $10 \mu \mathrm{l}$ of $\mathrm{ddH}_{2} \mathrm{O}$ was used for amplification of Leishmania genomic DNA.

\section{Amplification of Leishmania DNA}

Clinical isolates were characterized based on the size of their minicircle DNA as previously described [16]. $10 \mathrm{ng}$ of parasite DNA was amplified using two primers (AJS3 and DBY). The primer position is on the conserved region of the minicircle DNA and encompassing part of the sequence of origin of replication. In amplification, these primers yielded a whole length minicircle sequence, which differs between the different Leishmania species. Another PCR was performed, in which the COII gene was targeted. In this PCR procedure $10 \mathrm{ng}$ of genomic DNA was added to $46 \mu \mathrm{l}$ of the PCR mix, which consisted of $3 \mu 11$ of each primer. The optimal conditions for COII amplification were $3 \mu \mathrm{l}(15$ $\mathrm{pmol} / \mu \mathrm{l}$ ) of each primer (forward: 5' GGCATAAATCCATG TAAGA 3'; reverse: 5' TGGCTTTTATATTATCATTTT 3'), $1 \mathrm{U}$ Taq polymerase, $2 \mu \mathrm{l}$ dNTPs, $4 \mu \mathrm{l}$ PCR buffer, $3 \mu 1$ of $25 \mathrm{mM} \mathrm{MgCl} 2$ and $31 \mu \mathrm{l}$ of PCR H2O. PCR amplification was performed with a DNA thermocycler (PTC-100, MJ Research, Inc., Watertown, MA) with an initial denaturation step $\left(4\right.$ minutes at $94^{\circ} \mathrm{C}$ ), then 40 cycles of $94^{\circ} \mathrm{C}$ for 30 seconds, $45^{\circ} \mathrm{C}$ for 30 seconds (annealing), and $72^{\circ} \mathrm{C}$ for 2 minutes (extension).
The amplification reactions were analyzed by agarose gel electrophoresis, followed by ethidium bromide staining and visualization under UV light.

\section{Heteroduplex Analysis of Leishmania Amplified DNA}

Six ul of the COII amplification reaction of each Leishmania strain was transferred into $0.5 \mathrm{ml}$ PCR tube. An equal volume of amplification reaction from the reference strains was added into the same tube. The two DNAs were mixed together and then the tubes were placed in the thermocyler. All Leishmania DNAs were tested against DNA of L.infantum and L.donovani reference strains and against each other. The tubes passed through different temperature intervals $\left(94^{\circ} \mathrm{C}\right.$ for 5 minutes, $4^{\circ} \mathrm{C}$ for 5 minutes $)$ and finally left for 1 hour at $680 \mathrm{C}$. Heteroduplex reactions were run in $6 \%$ polyacrylamide gel supplemented with $3 \%$ $(\mathrm{w} / \mathrm{v})$ urea. The gel was pre-run for 30 minutes before samples loading, and then the gel was allowed to run 3 hours in a low-temperature atmosphere. The gel was silver-stained and bands were visualized under white light illumination.

\section{Restriction Fragment Length Polymorphism (RFLP)}

Five $\mu l$ of the amplification reaction was digested with the enzyme $S s p 1$ according to the manufacturer's instructions (BioLabs Inc. USA). The product of the digestion was loaded onto $2 \%$ agarose gel stained with ethidium bromide. Electrophoretic analysis was carried out in polyacrylamide gel for 90 minutes after which the gel was visualized.

\section{RESULTS}

Prior to HDA, all samples were subjected to DNA amplification using species-specific primers (AJS3-DB8) that amplify a whole length minicircle gene [7]. DNAs yielded bands of a molecular weight of $800 \mathrm{bp}$, which corresponds to the L.donovani complex minicircle size, thus confirming the identity of the parasites analyzed (Fig. 1). Reference strains are already characterized by isoenzymes as well as by DNA analysis. As well, HDA yielded extra slow moving bands with a MW of about 630-640 bp (Fig. 2). The PCR amplification of COII with two maxicircle primers, yielded bands

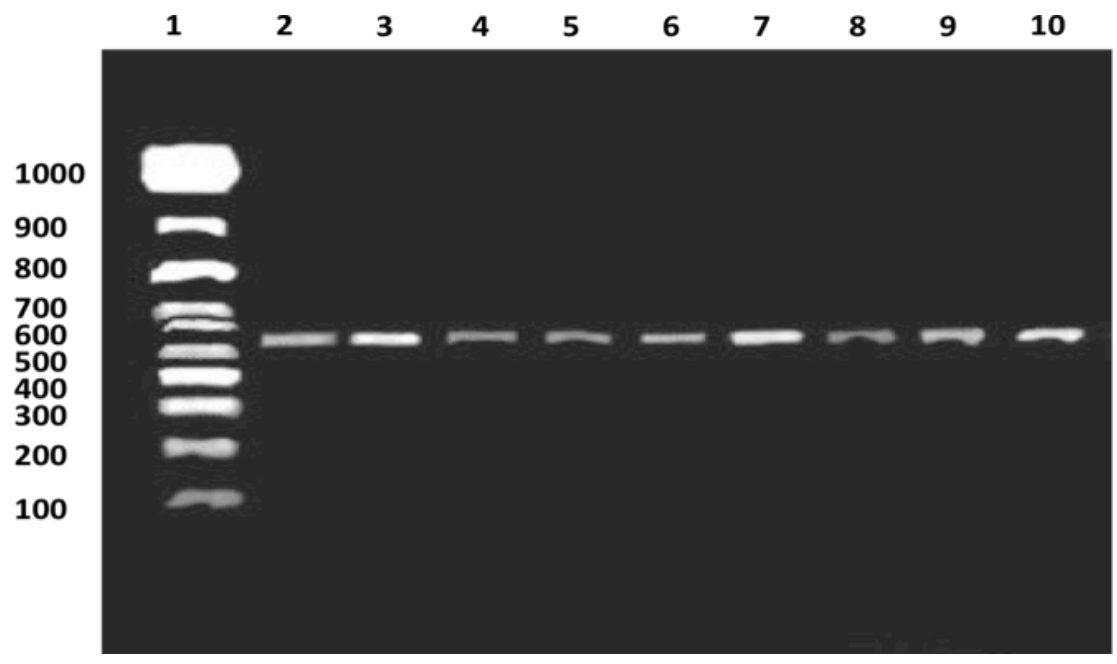

Fig. (1). PCR result of field isolates in addition to a reference strains using species-specific minicircle primers. The PCR product size is approximately 540 bp. Lane 1: 1kb marker (ladder); Lane 2: REBEL02; Lane 3: LEM307; Lanes 4-10: field isolates from Sudan. 


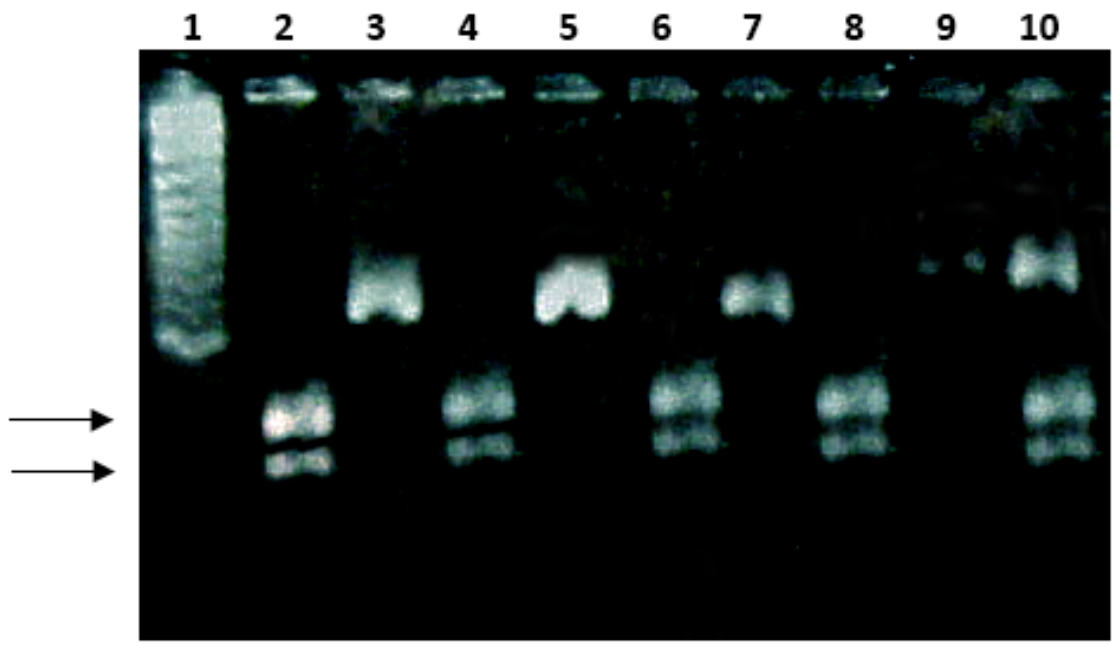

Fig. (4). RFLP using the enzyme Ssp1 on L.infantum reference strains (Lanes 2 and 3); L.donovani reference strains (Lanes 4 and 5); L. donovani field isolates (Lanes 6-10). Lane 1 is $1 \mathrm{~Kb}$ DNA marker. The Ssp1 cleaves a $540 \mathrm{bp}$ PCR product at a single recognition site in the case of L.donovani (upper arrow) and two recognition sites in the case of L.infantum, thus yielding different restriction size products (lower arrow).

site [17]. HDA is sensitive in detecting sequence differences down to a single base substitution $[18,19]$. However, other similar techniques for identifying single base substitutions are available like single strand conformation polymorphism (SSCP) and DNA sequencing [20]. Data on species-specific PCR assay for L.infantum/L.donovani discrimination has recently been reported [21]. HDA is a reasonable choice due to its relatively straightforward procedure. The presence of extra bands, rather than the main gene fragment, is taken as an evidence for difference in the DNA sequence by at least a single base pair. The two methods of HDA and RFLP could be applied separately or in a complementary fashion depending on the objective set by the investigator. We believe that this is a simple, rapid and easy to perform method for characterization of L.donovani complex strains and with a potential to be extended to other Leishmania species.

\section{ACKNOWLEDGEMENTS}

This work was financially supported by the Wellcome Trust and The TDR/WHO grant No. M8/181/4/S.496. We thank Dr. Jill Seaman from the MSF-Holland her help in lymph node and bone marrow aspirates and for providing the clinical data.

\section{ABBREVIATIONS}

$$
\begin{aligned}
& \text { HAD }=\text { Heteroduplex analysis } \\
& \text { RFLP }=\text { Restriction fragment length polymorphism } \\
& \text { COII }=\text { Cytochrome oxidase } \\
& \text { VL }=\text { Visceral leishmaniasis }
\end{aligned}
$$

\section{REFERENCES}

[1] McMahon-Pratt D. Report on Leishmaniasis Scientific Working Group. Geneva: World Health Organization; 2004. Mechanisms of pathogenesis - Differences amongst Leishmania species 37-9.
[2] Handman E, Elso C, Foote S. Genes and Susceptibility to leishmaniasis. Adv Parasitol 2005; 59: 1-75.

[3] Handman E. Leishmaniasis: status of vaccine development. Clin Micro Rev 2001; 14: 229-43.

[4] Schriefer A, Schriefer ALF, Goes-Neto A, et al. Multiclonal Leishmania braziliensis population structure in a region of endemicity for American tegumentary leishmaniasis. Infect Immun 2004; 72: 508-14.

[5] Marco JD, Barroso PA, Calvopina M, et al. Species assignation of Leishmania from human and canine American tegumentary leishmaniasis cases by multilocus enzyme electrophoresis in north Argentina. Am J Trop Med Hyg 2005; 72: 606-11.

[6] Le Blancq, SM Schnur LF, Peters W. Leishmania in the Old World: 1. The geographical and hostal distribution of L.major zymodemes. Trans Royal Soc Trop Med Hyg 1986; 80: 99-112.

[7] Ibrahim ME, Evans DA, Theander TG, El-Hassan AM, Kharazmi A. Diversity among Leishmania isolates from the Sudan: isoenzyme homogeneity of $L$. donovani versus heterogeneity of $L$. major. Trans royal Soc Trop Med Hyg 1995; 89: 366-9.

[8] Oskam 1, Pratlong F, Zijlistra EE, et al. Biochemical and molecular characterization of Leishmania parasites isolated from an endemic focus in eastern Sudan. Trans Royal Soc Trop Med Hyg 1997; 92: 120-2.

[9] Smyth AJ, Ghosh A, Hassan, et al. Rapid and sensitive detection of Leishmania kinetoplast DNA from spleen and blood samples of kala-azar patients. Parasitol 1992; 105 (Pt 2): 183-92.

[10] Mauricio IL, Gaunt MW, Stothard JR, Miles MA. Genetic typing and phylogeny of the Leishmania donovani complex by restriction analysis of PCR amplified gp63 intergenic regions. Parasitology 2001; 122(Pt 4): 393-403.

[11] Castilho TM, Shaw JJ, Floeter-Winter LM. New PCR assay using glucose-6-phosphate dehydrogenasefor identification of Leishmania species. J Clin Mic 2003; 41: 540-6.

[12] Foulet F, Botterel F, Buffet P, et al. Detection and identification of Leishmania species from clinical specimens by using a real-time PCR assay and sequencing of the cytochrome $b$ gene. J Clin Micro 2007; 45: 2110-5.

[13] Haouas N, Gorcii M, Chargui N, et al. Leishmaniasis in central and southern Tunisia: current geographical distribution of zymodemes. Parasite 2007; 14: 239-46.

[14] Spanakos G, Piperaki ET, Menounos PG, Tegos N, Flemetakis A, Vakalis NC. Detection and species indentification of Old World Leishmania in clinical samples using a PCR-based method. Trans Roy Soc Trop Med Hyg 2008; 102: 46-53.

[15] Miller SA, Dykes DD, Polesky HF. A simple salting out procedure for extracting DNA from human nucleated cells. Nucleic Acids Res 1988; 16: 1215.

[16] Ibrahim ME, Barker DC. The origin and evolution of The Leishmania donovani complex as inferred from a mitochondrial 
cytochrome oxidase II gene sequence. Infect Genet Evol 2001; 1: 61-8.

[17] Dereure J, Boni M, Pratlong F, et al. Visceral Leishmaniasis in Sudan: first identifications of Leishmania from dogs. Trans Royal Soc Trop Med Hyg 2000; 94(2): 154-5.

[18] Prior TW, Papp AC, Snyder PJ, et al. Heteroduplex analysis of the dystrophin gene: application to point mutation and carrier detection. Am J Med Gen 1994; 50(1): 68-73.

[19] Gayther SA, Harrington P, Russell P, Kharkevich G, Garkavtseva RF, Ponder BA. Rapid detection of regionally clustered germ-line
BRCA1 mutations by multiplex heteroduplex analysis. Am J Hum Gen 1996; 58: 451-6.

[20] El Tai NO, El Fari M, Mauricio I, et al. Leishmania donovani: intraspecific polymorphisms of Sudanese isolates revealed by PCRbased analyses and DNA sequencing. Exp Parasitol 2001; 97: 3544.

[21] Hide M, Banuls A. Species-specific PCR assay for L.infantum L.donovani discrimination. Acta Tropica 1006; 100: 241-5.

(C) Sharief et al.; Licensee Bentham Open.

This is an open access article licensed under the terms of the Creative Commons Attribution Non-Commercial License (http://creativecommons.org/licenses/by$\mathrm{nc} / 3.0 /$ ), which permits unrestricted, non-commercial use, distribution and reproduction in any medium, provided the work is properly cited. 